\title{
Televizyondaki Şiddet Çocuklarımızı Ne Kadar Etkiliyor?
}

\author{
Zahide Yalaki, E. Derya Potur, Sırma Ercan, F. İnci Arıkan, Ülkü Tıraş, Yıldız Dallar \\ Ankara Eğitim ve Araştırma Hastanesi Çocuk Sağlığı ve Hastalıkları Kliniğı, Ankara
}

\begin{abstract}
ÖZET
Televizyondaki siddet çocuklarımızı ne kadar etkiliyor?

Son zamanlarda özkıyım girişiminde yaş aralı̆ının küçülmesinde televizyonda (TV) görülen şiddet olaylarının da etkisi olduğu düşünülmektedir. Burada televizyonda seyrettikleri filmlerden etkilenerek özkıyım girişiminde bulunan küçük yaştaki olgular sunulmuştur. Ilk hasta olan dört yaşında kız çocuğu acil polikliniğimize başvurudan 30 dakika önce diklofenak sodyum içeren SR tabletten içme şikayeti ile ailesi tarafından getirildi. Hastanın öyküsünde babasından oyuncak mikrofon istediği, aldığı olumsuz cevap karşısında televizyonda izlediği bir filmde bir kızın ilaç içtiğini ve bir şey olmadığını gördüğü için kendisinin de ilaç içtiği öğrenildi. Genel durumu ve fizik muayenesi iyi olan hastada yapılan değerlendirmede hiperaktivite saptandı. íkinci hasta olan yedi yaşında kız çocuğu acil servise entübe, bilinci kapalı olarak getirildi. Hastanın öyküsünden, akşam annenin hastaya kızması nedeni ile kendi odasına giderek odayı kilitlediğini, ailenin 15 dakika sonra kapıyı kırarak odaya girdiğinde, hastanın kendisini oyun ipi ile yatak ranzasına asmış olarak buldukları öğrenildi. iki gün ventilatörde izlenen hasta, genel durumu düzelince kendini asma davranışını televizyonda seyrettiği bir filmde gördüğünü ifade etti. iki olgu da çocuk psikiyatrisi takibine alındı.

Çocukların TV'den gördükleri programlar aracıllğılala, sonunun nasıl olabileceğini bilmeden intihar davranış yolunu seçmelerinin kaygı verici olduğu düşünülmektedir. Şiddet içeren davranışları önlemede aile-çevre, medya ve televizyon programlarının daha dikkatli olmaları gerektiğini düşünmekteyiz.
\end{abstract}

Anahtar kelimeler: Çocuk, televizyon, özkıyım girişimi

\section{ABSTRACT \\ How violence on TV effect our children?}

The recent decrease in the age interval of children who commit suicide is thought to be related to the violent images seen on television (TV). Cases of two young children influenced by the films they watched on TV who attempted suicide are reported here. First case was a four year old girl brought to our emergency clinic by her family for taking pills of diclophenac sodium SR 30 minute prior to their arrival. Interview with the patient and her family revealed that, the four year old girl asked for a toy microphone from her father and when the father rejected, she recalled a girl taking pills on a TV film and since she saw that nothing happened to her, she took the pills herself. The patient's physical examination showed that her general condition was well; however, she was evaluated to have hyperactivity. Second case was a seven year old unconscious and intubated girl brought to our emergency clinic. Interview with her family revealed that, after reprehended by her mother, the girl locked herself in her room and after 15 minutes, when her family members broke the door open and entered her room, she was found hanging on a bunk bed with a play rope. The patient was monitored on a ventilator for two days and after she recovered, she explained that she saw the act of hanging self on TV. Both patients were cared by psychologists.

We think that it is very worrying to see some kids attempting suicide without knowing the consequences. We believe that in order to prevent violent behavior, more care should be taken in family-environment, media and TV programs.

Key words: Child, television, suicide attempt

\section{Giriş}

Ö zkıyım davranışının temelinde kendine zarar verme amacı bulunmaktadır (1). Gelişmiş ve gelişmekte

Yazıșma adresi / Address reprint requests to: Uzm. Dr. Zahide Yalaki Ankara Eğitim ve Araştırma Hastanesi Çocuk Sağlığı ve Hastalıkları Kliniği Mamak, Ankara

Telefon / Phone: +90-312-595-3840

Elektronik posta adresi / E-mail address: dr_zahide@yahoo.com Geliş tarihi / Date of receipt: 22 Eylül 2010 / September 22, 2010 Kabul tarihi / Date of acceptance: 2 Kasım 2010 / November 2, 2010 olan ülkelerde özellikle adolesan yaş grubu çocuklarda özkıyım girişimleri önemli bir halk sağlığı sorunudur. Son yıllarda özkıyım girişiminde bulunan adolesan yaş grubu çocukların sayısı giderek artmaktadır $(2,3)$.

Ergenlik dönemindeki özkıyım girişimi için risk faktörlerini araştıran çalışmalar, önceki özkıyım girişimleri, hastalık, aile içi şiddet, madde kullanımı, fiziksel-cinsel istismar gibi nedenler üzerinde durmaktadır (4-7).

Bu nedenlerle beraber sokakta, okulda, evde, televizyondaki bazı programlarla daha küçük yaştaki çocuklar da çeşitli şekillerde şiddet ortamında kalmaktadır. Bu tür 
görsel şiddetin öğrenilmesi ile de çocuklarda özkıyım girişimlerinin arttığını düşünen yayınlar bulunmaktadır $(8,9)$. Burada televizyonda seyrettikleri filmlerden etkilenerek özkıyım girişiminde bulunan küçük yaştaki olgular sunulmuştur.

\section{OLGU SUNUMU}

\section{Olgu 1}

Dört yaşında kız hasta çocuk acil polikliniğimize başvurudan 30 dakika önce diklofenak sodyum SR içeren tabletten 4 adet içme şikayeti ile ailesi tarafından getirildi. Hastanın öyküsünde babasından oyuncak mikrofon istediği, aldığı olumsuz cevap karşısında televizyonda izlediği bir filmde bir kızın ilaç içtiğini ve bir şey olmadığını gördüğü için kendisinin de dolaptan aldığı ilacı içtiği öğrenildi. Ailenin ilk çocuğuydu, özgeçmiş ve soy geçmişinde bir özellik yoktu. Hastanın başvurusundaki fizik muayenesinde: genel durumu iyi, bilinci açık, solunum sayıSI: 24/dk, kalp tepe atımı (KTA): 104/dk, vücut ISISI (VI): $36.8^{\circ} \mathrm{C}$, kan basıncl (KB): 80/60 mmHg idi. Sistem muayenesi doğal idi. Hastaya mide lavajı yapıldı, aktif kömür verildi. Zehir danışma tarafından alınan miktarın toksik düzeyde olmadığı öğrenildi. Laboratuar tetkiklerinde; tam kan sayımı, karaciğer-böbrek fonksiyon testleri, protrombin zamanı (PTZ), parsiyel tromboplastin zamanı (PTT) normal olarak bulundu. Hastanın babası kızının ilaç içme durumunu kabullenemedi ve kızını görmek istemedi. Sosyal hizmetler birimine, çocuk ve erişkin psikiyatrisine danışıldı. Hastada hiperaktivite, babada anksiyete bozukluğu saptandı. Sosyal hizmetler birimi hastayı takibe aldı. İzleminde ilaç yan etkisi görülmeyen hasta, çocuk psikiyatrisinin takibine gitmek üzere taburcu edildi.

\section{Olgu 2}

Yedi yaşında kız hasta hastanemiz acil servisine entübe, bilinci kapalı olarak ambulans ile getirildi. Hastanın öyküsünden, akşam annenin hastaya kızması nedeni ile kendi odasına giderek odayı kilitlediğini, ailenin 15 dakika sonra kapıyı kırarak odaya girdiğinde, hastanın kendisini oyun ipi ile yatak ranzasına asmış olarak buldukları öğrenildi. Ambulans ekibi ile evden alınan hastanın yolda 2 kez konvülziyon geçirdiği, idrar-gaita inkontinansının geliştiği öğrenildi. Hastanın başvurusundaki fizik muayenesinde; bilinci kapalı, ışık refleksi vardı, pupilleri izokorik,
KTA: $110 / d k$, spontan solunumu yoktu. KB: $80 / 50 \mathrm{mmHg}$ VI: $36.8^{\circ} \mathrm{C}$, kan şekeri: $104 \mathrm{mg} / \mathrm{dl}$ idi. Sistem muayenelerinde boyunda asıya bağlı ip izi (ekimoz ve peteşi) dışında patolojik bulguya rastlanmadı. Laboratuar tetkiklerinde; tam kan sayımı, karaciğer-böbrek fonksiyon testleri, PTZ, PTT normal idi. Hasta ventilatörde izleme alındı. Bakılan arter kan gazı normal bulundu. Antikonvülzan olarak midazolam infüzyonu, kranial tomografisinde beyin ödemi saptanan hastaya steroid ve mannitol verildi. Tedavinin 48. saatinde bilinci açılan, solunumu düzelen hasta ventilatörden ayrıldı. Çocuk psikiyatrisine danışılan hastanın, kendini asma davranışını televizyonda seyrettiği bir filmde gördüğünü, annesi kendisine kızdığı için kendini astığını ifade ettiği öğrenildi. Sosyal hizmetler birimi ve Çocuk psikiyatrisi tarafından hasta izleme alındı. Çocuk nöroloji polikliniğinde de, ilerleyen dönemde gelişebilecek hipoksik sekelin izlemi açısından kontrollere gelmek üzere taburcu edildi.

\section{TARTISSMA}

Özkıyım girişimi dünyada olduğu gibi ülkemizde de önemli bir sorundur. Ergenlerde özkıyım girişimlerinin yaşam boyu prevalansının \%3.5-11 arasında olduğu bildirilmektedir (1). Türkiye'de 5-14 yaş arası özkıyım hızı 1990 'da milyonda 3.37 olarak tespit edilmiştir $(3,10)$. A.B.D.'de 10-19 yaş grubunda ölüm nedenleri içinde özkıyım girişimi üçüncü sırada yer almaktadır $(11,12)$. Yine ABD'de 2001-2004 yılları arasında 10-19 yaş grubunda \%23 oranında özkıyım girişiminde artış olduğu saptanmıştır. Özellikle 10-14 yaş grubunda 2001 yllında 15858 özkıyım vakası görülürken 2004 yılında bu sayı 22790 olarak saptanmış ve 10-14 yaş grubunda özkıyım girişimlerinin \%30 oranında arttığı, adolesan dönemdeki özkıyım vakalarının görülme yaşının küçüldüğü saptanmıştır (12).

Özkıyım girişiminde yaş aralığının küçülmesinde televizyonda (TV), medyada, sokakta, okulda görülen şiddet olaylarının da büyük bir etkisi olduğunu düşünmekteyiz. Son zamanlarda haberlerde, gazetelerde çıkan küçük yaştaki çocukların özkıyım girişiminde bulunma haberleri de bu düşüncemizi doğrular niteliktedir. Bizim 2 olgumuzda da yaş aralığının ne kadar küçüldüğü görülmektedir. Bu kadar küçük yaşlarda özkıyım girişimi düşüncesinin olmasında TV'nin de etkisi olduğu düşünülmektedir Dört yaşındaki birinci olgumuz TV'de gördüğü filmdeki davranışı tekrarladığını ifade etmiştir. Yedi yaşındaki ikinci olgu da benzer şekilde kendini asma davranışını TV'de 
anne-babasıyla izlediği bir filmde gördüğünü söylemiştir. RTÜK Iletişim Dergisi'ne göre de aileler TV'de yer alan şiddet içerikli filmlerden, haberlerden ve çizgi filmlerden rahatsız olmakta ve şikayette bulunmaktadırlar (13).

Kitle iletişim araçlarının saldırganlık ve şiddet olaylarının ortaya çıkmasında ve artmasında bir payının bulunup bulunmadığı tartışma konusudur. Artan şiddet olayları ile belirgin bir bağlantısı olmasa bile kitle iletişim araçlarının şiddete yönlendirme ve etkilemesi üzerinde görüş birliğ vardır $(8,9)$.

Çocuğun gelişim evrelerine bakıldığında; 4-7 yaş döneminde mantıksal düşünce henüz gelişmemiştir. Bu dönemde çocukların gördükleriyle bildikleri sınırlıdır. Çocukların TV'den etkilenmeleri bu dönemde yüksek olasılıktır. Çünkü bu dönemde çocuk gördüklerini daha çok taklit eder. Gerçek ile hayali birbirinden tam olarak ayırt edemez. Dolayısıyla çocuk TV'de gördüğü bir sahneden etkilenip gerçek hayatla bağdaştırabilir ve taklit etme yoluna gidebilir $(14,15)$. Birinci olgumuz da babasına kızdığı için TV'de gördüğü 'istediği yapılmayınca ilaç içen abla’ sahnesini kötü sonuçlara yol açabileceğini bilmeden tekrarlamıştır. i̇kinci olgumuz da TV'de gördüğü sahnelerden etkilenerek ailenin kendisine kızması sonucu, kendisinin de aileye karşı tepki olarak yatak ranzasına astığını ifade etmiştir.

Televizyon yetişkinler açısından haber alma, eğlenme aracıyken, çocuklar için eğlendirme aracı olmanın yanında toplumu, dünyayı tanıma-anlama aracıdır. Küçük çocuklar bu nedenle TV'de gördüklerinin hangilerinin gerçek hangilerinin hayal ürünü olduğunu kolaylıkla aylramazlar (9). Bu nedenle sonunun nasıl olacağını bilmeden gördüklerini, duyduklarını taklit etme yoluna gidebilirler.

Küçük yaştaki çocuk özkıyımlarında tek başına TV, medyayı suçlamanın doğru olmadığını düşünmekteyiz.
Ailelerin çocukları ile yeterince ilgilenip ilgilenmemesi de önemlidir. Ailenin TV seyretme alışkanlığı, seyrettiği programların içeriği, şiddet sahnesi içeren programlar sırasında TV kanalının değiştirilmesi, çocuğa seyrettiği program konularının hangisinin gerçek hangisinin hayal olduğunun anlatılması, çocuğun TV seyrederken yalnız bırakılmamasının da önemli olduğunu düşünmekteyiz.

Amerika, Fransa ve Ingiltere'de 1990'dan sonra çocukların ve gençlerin duyarlılı̆ını zedeleyebilecek yayınları düzenlemeye yönelik girişimler başlatılmıştır (15). Çocuklar için uygun olmayan şiddet içerikli, özkıyım ve özkıyım girişimleri içeren yapımların çocukların izleyebileceği saatlerde yayınlanmaması ilkesi getirilmiştir (15). Ülkemizde de 1995'ten sonra kIsmen de olsa RTÜK tarafından bazı düzenlemeler yapılmaya çalışılmıştır (15). Ancak buna rağmen şiddet içerikli programlar, hatta çizgi filmler TV'de gösterilmeye devam etmekte ve çocuklar bunları seyretmektedir.

Özkıyım girişiminde bulunan çocuk ve adolesanların psikiyatrik değerlendirmeleri yapıldığında depresyonun da intihar davranışında önemli bir yer tuttuğu gösterilmiştir $(5,10)$. Olgularımızın çocuk psikiyatrisi tarafından yapılan değerlendirmelerinde; 4 yaşındaki olguda hiperaktivite, olgunun babasında yapılan psikiyatrik değerlendirmede ise anksiyete bozukluğu saptandı. Yedi yaşındaki olguda çocuk psikiyatrisi tarafından takibe alındı.

Sonuç olarak, özkıyım davranışında bulunan çocukların yaş ortalamasının küçülmesi, çocukların TV'den gördükleri, duydukları şeyler aracılığıyla, sonunun nasıl olabileceğini bilmeden özkıyım davranış yolunu seçmelerinin kaygı verici olduğu düşünülmektedir. Bu tür şiddet içeren davranışları önlemede aile-çevre, medya ve televizyon programlarının daha dikkatli olmaları gerektiğini düşünmekteyiz.

\section{KAYNAKLAR}

1. Atay IM, Kerimoğlu E. Ergenlerde intihar davranışı. Çocuk ve Gençlik Ruh Sağlığı Dergisi 2003: 10: 128-136.

2. Kurihara $T$, Kato $M$, Reverger $R$, Tirta IG. Suicide rate in Bali. Psychiatry Clin Neurosci 2009; 63: 701.

3. Duman $\mathrm{M}$, Özdemir $\mathrm{D}$, Demir $\mathrm{K}$ ve ark. Çocuk acil servisine intihar girișimi ile başvuran olguların özellikleri. Dokuz Eylül Üniversitesi Tıp Fakültesi Dergisi 2004; 18: 236-240.

4. Aktepe E, Kandil S, Göker Z, ve ark. Intihar girişiminde bulunan çocuk ve ergenlerde sosyodemografik ve psikiyatrik özelliklerin değerlendirilmesi. TAF Prev Med Bull 2006; 5: 444-454.

5. Sayar K, Öztürk M, Acar B. Aşırı dozda ilaç alımıyla intihar girişiminde bulunan ergenlerde psikolojik etkenler. Klinik Psikofarmakoloji Bülteni 2000: 10: 133-138.

6. Schwartz KA, Pyle SA, Dowd MD, Sheehan K. Attitudes and beliefs of adolescents and parents regarding adolescent suicide. Pediatrics 2010; 125: 221-227.

7. Yendur G, Serdaroğlu G, Oral R, Yavuz S, Kavaklı T. Çocuk istismarı sonrası intihar girişimi. T Klin Ped 1998; 7: 100-102.

8. Kaskun A, Öztunç S. Çocuk, televizyon ve şiddet. İletişim Fakültesi Dergisi 2002: (http://ilef.ankara.edu.tr) 
9. Adak N. Bir sosyalizasyon aracı olarak televizyon ve şiddet. Bilig 2004; 30: 27-38

10. Aktepe E, Kandil S, Topbaş M. Çocuk ve ergenlerde intihar davranışı TSK Koruyucu Hekimlik Bülteni 2005; 4: 88-97.

11. Koplin B, Agathen J. Suicidality in children and adolescents: a review. Curr Opin Pediatr 2002; 14: 713-717.

12. Pomerantz $\mathrm{W}$, Gittelman $\mathrm{M}$, Farris $\mathrm{S}$, Frey L. Drug ingestions in children 10-14 years old: an old problem revisited. Suicide Life Threat Behav 2009; 39: 433-439.
13. Bayraktar Z. RTÜK'ten kötü haber. RTÜK Illetişim Dergisi 2000; 4 33-34.

14. Ekşi A (Ed). Cocukluk döneminde uyum ve davranış sorunları. "Ben hasta değilim. Çocuk sağlığı ve hastalıklarının psikososyal yönü". 1.baskı; İstanbul: Nobel Tıp Kitabevleri, 1999; s. 98-106.

15. Öksüz S. Çocuk ve etik. RTÜK Iletișim Dergisi 2000; 4: 35-38. 